\title{
The Constitutionalisation of Contract Law in Finland
}

\section{Husa, Jaakko}

Springer

2019-09

Husa , J \& Karhu , J 2019, The Constitutionalisation of Contract Law in Finland . in L

Siliquini-Cinelli \& A Hutchison (eds), More Constitutional Dimensions of Contract Law : A

Comparative Perspective . Springer , pp. 15-39 . https://doi.org/10.1007/978-3-030-15107-2_2

http://hdl.handle.net/10138/331867

https://doi.org/10.1007/978-3-030-15107-2_2

unspecified

acceptedVersion

Downloaded from Helda, University of Helsinki institutional repository.

This is an electronic reprint of the original article.

This reprint may differ from the original in pagination and typographic detail.

Please cite the original version. 


\section{CONSTitutional CONTRACT LAW - FinLAND}

Jaakko Husa and Juha Karhu

\section{Introduction}

How constitutional law and contract law are related in Finland? This question cannot be answered straightforwardly. The Finnish legal system is, generally speaking, based on the Nordic and Continental European traditions. ${ }^{1}$ In practice, Finnish law and legal culture are especially in key areas of private law such as contract law, tort law, and company law close to the Swedish system. In fact, Nordic contract laws were shaped and drafted in close legislative co-operation. ${ }^{2}$ However, there are significant differences in Nordic constitutional traditions and when dealing with constitutional contract law there are less similarities than otherwise because of national Nordic constitutional characteristics differ in many respects although there are also many essential similarities. ${ }^{3}$

This chapter deals with the Finnish contract law and constitutional law related themes and questions. In this chapter, where appropriate, comparative remarks and comments especially in relation to the other Nordic systems will be made. Moreover, the discussion seeks to predict some key future developments concerning constitutional contract law in Finland. The remainder of this paper is organized as follows: after this introduction, the constitutional landscape will be dealt with in chapter 2. Chapter 3 deals with the fundamentals of contract law and explains the key content and ideas of the Finnish contract law. Then, chapter 4 illustrates how relevant constitutional actors take constitutional law and contract law into account and how these actors may sometimes collide because of the constitutional structure

\footnotetext{
${ }^{1}$ See Jaakko Husa, 'The Stories We Tell Ourselves - About Nordic Law in Specific', Isaidat Law Review 1 (2011) Article 9 (available at SSRN: https://ssrn.com/abstract=2176029 or http://dx.doi.org/10.2139/ssrn.2176029).

${ }^{2}$ See for example Mads Bryde Andersen and Eric Runesson, 'An Overview of Nordic Contract Law', in: The Nordic Contracts Act. Essays in Celebration of its One Hundredth Anniversary (2015) 15-41 and Ole Lando, A Short Survey of the Laws of the Nordic Countries - the Laws in General and Contract Law in Particular, in: Restatement of Nordic Contract Law (2016) 13-45. However, from today's point of view we may also see problems with the Scandinavian Contract Act. See the critical discussion by Christina Ramberg, 'The Hidden Secrets of Scandinavian Contract Law', Scandinavian Studies in Law 50 (2007) 249-256.

${ }^{3}$ See, e.g., Markku Suksi, 'Markers of Constitutional Identity', Retfaerd 37 (2014) 66-91 (speaks of 'Nordicness').
} 
and key doctrines. The final chapter draws together the main themes and findings added with a critical discussion.

\section{Constitutional Landscape}

\subsection{Finnish Constitution}

The Constitution of Finland is technically enshrined in a single Act i.e. the Constitution of Finland that entered into force 2000. ${ }^{4}$ Before the present constitution Act, there were four separate constitutional Acts - following the Swedish tradition - which were the Form of Government (1919), the Procedure of Parliament (1922), the Ministerial Responsibility Act (1922), and the Act on the High Court of Impeachment (1922). In essence, the Constitution Act provides the catalogue of constitutional rights and provisions on the principles of the exercise of public power by Government, Government's organisation and the relationships between the highest organs of the state. In 2012, the Constitution Act was amended. These amendments clarified the division of powers between the President of the Republic and the Government.

Finland is a parliamentary democracy with certain semi-presidential elements i.e. it has a President as the head of state and with certain competences that are listed in the Constitution Act. On the day-to-day basis, the Finnish system functions as a parliamentary system and the President has a minor role in non-foreign relations related politics (which include also most of EU policies). As a general remark we can say that the Finnish governance normally works so that it seeks consensus rather than partisan solutions backed by temporary majority i.e. constitutional culture strives towards consensus. ${ }^{5}$ This produces certain rigidity i.e. the Constitution, both in legal and political sense, changes relatively slowly.

The Finnish system is based on core principles according to which power is vested in the people, who are represented by deputies assembled in Parliament. Crucially, legislative

\footnotetext{
${ }^{4}$ This section is based on Jaakko Husa, The Constitution of Finland - A Contextual Analysis (Oxford, Hart, 2011).

${ }^{5}$ For a broader view, see Tapio Raunio, 'The Changing Finnish Democracy', Scandinavian Political Studies 27 (2004) 133-152.
} 
power is exercised by the Parliament whereas the President of the Republic has a minor role. According to the constitution Act the top level of governance is in the Council of State (i.e. the Government) which is headed by a Prime Minister and a requisite number of other ministers. Following the principle of parliamentary system Government and its individual members must have the confidence of the Parliamentary majority. Another key point is that judicial power is vested in independent courts of law, at the highest level in the Supreme Court and the Supreme Administrative Court. ${ }^{6}$ Of these top courts, the Supreme Court has an important role in the birth and evolution of constitutionally relevant contract law.

\subsection{Contract and Constitution}

In essence, the Constitution provides the catalogue of constitutional rights and provisions covering the main principles of the exercise of public power by Government, Government's organisation and the relationships between the highest institutions (executive, legislative, and judicial branches) of the state. In 2012, the Constitution was amended but these amendments did not concern constitutional rights. Besides constitutional rights, also human rights and especially the European Convention on Human Rights (ratified in 1990) and the case law of the European Court of Human Rights are relevant for constitutional contract law.

Basically, in the Finnish Constitution there is no express Section dealing with contract, contracting or freedom of contract in general nor is there direct reference to the basic social or economic values in relation to contracts. However, it is generally acknowledged that Finnish Constitution indirectly provides a legal protection of freedom of action also in private law relations, and that the protection of property encompasses the protection of (freely created) contractual relations (i.e. they are considered to constitute private property in a broad sense).

More concretely, the legal protection provided by the constitutional right is constructed as two dimensions in legal reasoning. Firstly, fundamental rights are normally expected to be implemented through parliamentary legislation. Legislation providing contracts is composed

\footnotetext{
${ }^{6}$ About the institutional structure, see Husa (2011) 41-50 and Ilkka Saraviita, Constitutional Law in Finland (Kluwer Law International, Alphen aan den Rijn, 2012) 237-250.
} 
of one general piece of legislation, the Finnish Contracts Act (FCA; originally from 1929), and several specific Acts in separate areas of law (sales law, including consumer law, insurance law, real estate law, etc.). Secondly, and from the point of view of content, FCA, like its Nordic counterparts, contains a general norm (Section 36, added in Finland in 1983) enabling the adjustment of unfair contracts. The Section 36, as a provision enabling a general evaluation of the fairness of all contacts and their terms, is considered a part of the "ordre public" of the Finnish contract law system. Therefore, the application of foreign contract law is blocked if it does not recognize the possibility of adjustment of unfair contracts.

Because of the open list of circumstances that can be taken into account when considering the unfairness, the Finnish contract law system is open for human right and/or constitutional right dimension as a part of legal argumentation and judicial decision-making. For example, the argument based on the constitutional right to access to justice have been used to block the application of an arbitration clause in a business contract in situation where the arbitration proceedings would not have been effective because the lack of resources of the other party to pay the required guarantee down payments for the arbitration court's expenses and fees, and the arbitration proceedings would not have been started at all but still legally blocking the proceedings in a general court of law. Thus, Section 36 can be seen as a kind of general entrance gate to test and include constitutional aspects in contract law reasoning.

In a broader view, the constitutional dimension of contract law is connected to the right of economic self-determination that, in turn, is related besides to the freedom of trade and profession also broadly understood protection of property in Finland. To simplify a great deal, constitutionally protected property effects on the legal validity of contracts. In essence, the right to property contains a bundle of such rights that have economic value i.e. all parties' legitimate expectations of fair economic benefit from the contact are protected. In practice, this means that enjoying the constitutional right to property requires protection of the freedom of contract meaning that there is a freedom of individuals or legal entities to enter into contracts and decide the contents of their contractual relations without the interference of the state or unwarranted legislative restrictions. Typically, the economic value of constitutional property right comes from the fact that individual or legal entity can make an agreement with economic value based on its own plans and calculations. In other words, even if the freedom of contract is not constitutionally protected as such, it enjoys constitutional protection indirectly. Already before the reform of fundamental rights in 1995 existing 
contractual relations were constitutionally protected when they could be seen as normal and reasonable use of property. Thus, contract law has factual constitutional dimension on the basis of what can be arguably characterised as constitutional customary law.

Moreover, we can see that the idea of freedom of contract is in many ways an underlying dimension in the system of constitutional rights: there are economically relevant constitutional rights that can be deployed mainly or sometimes even only by means of making legally binding agreements between parties. For example, the right to choose one's profession and employment or place of stay requires normally contracts enabling these choices. In relation to access to justice, the freedom of contract is an important part of the rule of law principle that protects also the rights of a claimant. To put it differently, the rights and duties of all parties belong to the constitutionally protected right to property. However, as a constitutional right, the right to property cannot be conceived only by itself and in isolation but it must be seen as a part of the system of constitutional and human rights are deployed. ${ }^{7}$

After the constitutional rights reform in 1995 references in legal practice to constitutional and human rights have increased significantly. These rights are applied a posteriori by the courts and other judicial and supervisory bodies and not anymore only by the Constitutional Committee a priori. ${ }^{8}$ After 1995, there has been clear development towards heightened role for constitutional law and human rights law in the area of contract law. Characteristically, contract law has been one of the "testing grounds" for the whole area of civil law to replace the sole value of freedom by human rights and constitutional rights. ${ }^{9}$ These constitutionally relevant innovations foreshadow a change in the basic legal concepts as well as in the principles. What is more, instead of abstract concepts of legal subject and legal relation open and contextual concepts of interest parties and risk positions may be used as basis for legal analyses and judicial argumentation. Moreover, traditional systematic doctrines like abuse of rights, good faith, and unfairness could receive concrete content, and even the role of "ordre public intern", by reference to human rights and constitutional rights.

\footnotetext{
${ }^{7}$ Pekka Länsineva, Perusoikeudet ja varallisuussuhteet [Fundamental Rights and Property Relations] (Helsinki, Suomalainen Lakimiesyhdistys, 2002).

${ }^{8}$ Cf. Pekka Länsineva, 'Fundamental Principles of the Constitution of Finland', in Introduction to Finnish Law and Legal Culture (eds.) Kimmo Nuotio, Sakari Melander, Merita Huomo-Kettunen (Helsinki, Faculty of law, 2012) pp. 111-125, 117-119.

${ }^{9}$ See Juha Pöyhönen (Karhu), Uusi varallisuusoikeus [A New Theory of Property Rights] (Helsinki, Talentum, 2003).
} 
In addition, constitutionalisation of Finnish private law in general and contract law in particular might also have a reverse effect: the privatization of Constitution. This tendency is fuelled by private outsourcing of many welfare state functions, especially in the areas of health care and basic social aid. Concretely these situations are hybrids consisting of elements originating both from private and public law realms. Constitutional rights have a key constructive role in the understanding of the interrelations of these often conflicting elements.

\subsubsection{Constitutional Rights}

Even though it is not a simple task to pinpoint how constitutional law and contract law became partially intertwined it is, nonetheless, clear that the rise of constitutional right is intimately connected to this process. Contract law and constitutional have had connections in the Finnish system for a long time, mostly through wide interpretation of the protection of property already under the old constitutional norms from 1919 based on even older Swedish norms, as described more below. Nevertheless, when we are dealing with the contemporary conception of constitutional rights we need to underline the role and significance of the comprehensive reform that entered into force on August 1995. Furthermore, especially the ECHR functioned as a key inspiration for this reform. In practice, the present Constitution Act in force contains comparatively speaking very comprehensive list of constitutional rights. There are classical civil and political rights but also much more modern economic, social, and cultural rights.

In certain parts, the Finnish catalogue of constitutional rights goes beyond the scope the ECHR. For instance, the catalogue contains specific provisions regarding environmental rights including everyone's responsibility for the environment. In addition, also other human rights instruments may have significance in relation to contract law. ${ }^{10}$ In general, we can claim that the Finnish constitutional culture has transformed into much more rights oriented than what was the case before and this development has taken place paralleled with the

\footnotetext{
${ }^{10}$ Importantly, The Council of Europe's revised European Social Charter has been in force since 2002. And, the EU Charter of Fundamental Rights also contains a wide range of ESC rights that may have relevance in context of contract law. What is more, there are other important conventions such as are the European Convention on Social Security and many several International Labour Organization (ILO) conventions and recommendations.
} 
heightened profile of constitutional judicial review. ${ }^{11}$ Transformation of Nordic legal culture has, however, not been an easy process but it remains a fact that rights are now more important within the Nordic legal cultural sphere than what they were earlier. ${ }^{12}$

Crucially, it would be not quite right to point out only one or two constitutional rights and argue that they would form the constitutional contract law in Finland. In fact, many occasions are such that different constitutional rights dimensions are interlinked and overlapping. From a business perspective, contractual rights are often linked with freedom of profession and other market related rights. Notwithstanding, we can underline the significance of the Section 15 of the Constitution Act which concerns the protection of property.

The Constitution Act's Section 15 is very sparse in its wording. It does not provide too much information about the precise content of the constitutional protection of property. ${ }^{13}$ In essence, this Section states in somewhat laconic way that the property of everyone is protected and that a provision concerning expropriation must be laid out in a Parliamentary Act. Moreover, Section 15 also restricts the constitutionally possible scope of expropriation legislation by stating that expropriation can be done strictly for public needs and against full compensation. Although the constitutional right to property has deep historical roots in the Finnish system, it was actually codified as late as 1919 in the Form of Government. Yet, if we look at the interpretation practice of the Constitutional Committee we can see that this right has been applied very often throughout the years of independent Finland (1918-), and then quite often as a restriction to economic and social reforms (protection of existing economic relations).

After the reform of 1995, the practice of the Constitutional Committee has been expanding in the sense that the protection of property is still conceived in a relatively broad manner but also more as a part of the whole system of constitutional and human rights. For instance, today there is more room for group rights which, on the other hand, may also restrict the scope of broadly understood right to use one's property in relation to constitutional

\footnotetext{
${ }^{11}$ See for a broader discussion, Juha Lavapuro, Tuomas Ojanen, Martin Scheinin, 'Rights-based constitutionalism in Finland and the development of pluralist constitutional review', International Journal of Constitutional Law 9 (2011) 505-531.

12 See Jaakko Husa, Nordic Constitutionalism and European Human Rights - Mixing Oil and Water? Scandinavian Studies in Law 55 (2011) 101-124.

${ }^{13}$ Section 15 provides that 'Provisions on the expropriation of property, for public needs and against full compensation, are laid down by an Act.'
} 
environmental rights. ${ }^{14}$ In fact, property rights are certainly not anymore - if they ever were absolute rights even though constitutional right to property still holds a strong position in the constitutional system of rights. What is more, it seems that the Finnish protection of property right is more far-reaching than the ECHR's conception of property, especially in the question how the 'possession' is defined and understood. ${ }^{15}$

A key indication of the strong status of right to property is the landmark case concerning constitutional judicial review decided in 2004 by the Supreme Court. The case was about the protection of property. In short, the owner of a building was stopped being able to benefit from premises because of temporary prohibition by public authority ("interior of value" cultural environment protection). Later the prohibition was cancelled and the owner demanded compensation. However, the Parliamentary Act in question provided possibility to get compensation only because of permanent prohibition, not of a temporary one. The Supreme Court held (split decision) that the provision in the Act was clearly contradictory with Constitution Act's property right. ${ }^{16}$ This was the first case in which the Supreme Court overruled a provision in the Parliamentary Act based on leading to unconstitutionality in a concrete case.

Now, this landmark case dealt with the protection of ownership of a building in the context of protection of cultural environment. The analogy to contractual relations is visible by seeing contractual relations as possible risk positions for further actions (as in the case the housing company's possibility to rent the space for another purpose than it was designated). Moreover, a similar line of legal argumentation is established by choosing the perspective of legitimate expectations. What is protected is not only (or mainly) a static position (as a negative protection against intrusions by outsiders) but the freedom of action in future based on the - to use a German expression - "Geschäftsgrundlage" adopted by the contract parties. This is also in line with the "bundle of rights" idea behind the constitutional understanding of property.

\footnotetext{
${ }^{14}$ Section 20 on the responsibility for the environment provides that 'Nature and its biodiversity, the environment and the national heritage are the responsibility of everyone.

The public authorities shall endeavour to guarantee for everyone the right to a healthy environment and for everyone the possibility to influence the decisions that concern their own living environment.'

${ }^{15}$ See Husa (2011) 186-187.

${ }^{16}$ KKO 2004:26
} 
This line of argumentation can be seen in the practice of Constitutional Committee. Two examples can highlight this. There are special housing company arrangements

("asumisoikeus") where the persons or families living in the flat are in between of owners and tenants. They pay a certain threshold sum to the housing company when entering into the relationship, and monthly rents. The housing company is and remains the owner of the flats. These threshold payments had a high priority in case of bankruptcy of the housing company (meaning roughly that the tenants would be paid back the threshold sums before other nonmortgage creditors of the housing company). When this priority position was lowered by a new law (to enable the housing companies to get credit easier and cheaper), it was considered relevant to take into consideration the legitimate expectations by the tenants, even if these were not part of the rent contract (not written down or guaranteed in the contract between the tenants and the housing company). It played a role in the argumentation that the contractual arrangement was a part of housing arrangement, and especially long-term housing for families with limited resources, relating it to the fundamental right of decent living conditions. ${ }^{17}$ All the same, we can see that constitutional dimension was meaningful for the interpretation of a contractual issue.

Secondly, there have been introduced several national support mechanisms for Finnish agriculture throughout the last century, and they are in the need of constant alignment with EU agricultural policies ("tilatuki"). ${ }^{18}$ One of these national mechanisms has been long term agricultural loans with reduced interest rates. When these interest rates were raised because of the EU norms, and even if the unilateral raise was enabled in the contract terms of these loans and necessitated by the EU, Constitutional Committee gave significance to the legitimate expectations of the farmers requiring that no rapid changes were allowed in national agricultural policies if they would have essential detrimental effects on these loans as long term agricultural investments. Again, there was a link to other fundamental rights besides protection of property, and in this case the freedom to choose one's profession.

Crucially, as noted above, contract enjoys constitutional status as a part of broadly understood umbrella of protection of property provided by the Constitution Act and the accompanying interpretative practice by the Constitutional Committee and the Courts. This

\footnotetext{
${ }^{17} \mathrm{PeVL} 45 / 2002$ vp. [PeVL stands for "perustuslakivaliokunnan lausunto" i.e. Statement of the Constitutional Committee].

${ }^{18}$ PeVL 25/2005 vp.
} 
protection comes visible always when there are legislative proposals effecting the area of freedom of contract (either as relating to already existing contractual relations or as such to possibilities that belonged to the legitimate expectations of the involved parties in the normal course of things). In this sense it is safe to argue that contract law has a constitutional dimension in Finland i.e. there is something that can be labelled as constitutional contract law. In order to explain how these two fields of law come typically fused together we need to explain first how the constitutionality review works in Finland.

\subsubsection{Finnish system of constitutionality review}

As already mentioned above, there is no constitutional court in Finland, but courts are allowed and obligated to do judicial review of all legislation but only to a certain limited extent. After the total reform of the Constitution Act in 2000, it became possible for courts to practice judicial review of legislation. The idea of constitutionality, however, is not limited to judicial review only because in addition to courts also other public authorities are obliged to interpret legislation in such a manner that adheres to the Constitution and to the respect of constitutional and human rights. According to the Constitution Act (Article 106), the courts must give preference to the Constitution when they decide a case if the application of a Parliamentary Act would be in a manifest conflict (in Finnish "ilmeinen ristiriita") with the Constitution Act. There are handful of cases, starting as mentioned above from year 2004, in which courts have applied the Article 106. However, in the overall picture the judicial review by the courts plays a minor role when it comes to guarding the constitutionality of Parliamentary Acts. ${ }^{19}$ Lately, there are certain signs of the gradually growing constitutional role of the judiciary although often considered secondary and supplement to that of Constitutional Committee. ${ }^{20}$ If the role of judiciary becomes stronger, it makes sense to assume that constitutional dimensions of contract law will also become more significant and distinct.

In practice, the constitutionality of Acts laws is examined in advance i.e. before Act steps into force. Review mainly takes place in the Parliament's influential Constitutional Law

\footnotetext{
${ }^{19}$ See Husa (2011) 186-187.

${ }^{20}$ See Tuomas Ojanen, 'From Constitutional Periphery toward the Center - Transformations of Judicial Review in Finland', Nordic Journal of Human Rights 27 (2009) 194-207.
} 
Committee (Perustuslakivaliokunta). The function of this parliamentary bound control is to prevent in advance that Acts conflicting the Constitution would be enacted in the ordinary legislative procedure. From the constitutional point of view, Committee's key function is to issue Statements on bills sent to it for consideration and on the constitutionality of other legislative matters and their bearing on international human rights. Even while the Committee's members are ordinary members of the Parliament, the Committee calls experts (based on constitutional convention) to give evidence, and the Committee itself operates in a non-party political manner when giving its reports to the Parliament. These reports are official Statements and Government, which seeks to amend the bill provisions that the Committee has found to be unconstitutional before the bill is passed, respects them. If the unconstitutionality is significant it means, in practice, that the bill is withdrawn and Government has to think another way to proceed because in a multiparty-system Governments do not have the required qualified majority to change the Constitution Act.

Therefore, constitutional contract law related issues might surface in the work of the Constitutional Committee at Finnish Parliament when this Committee pre-reviews legislative Bills, thought to be potentially constitutionally problematic, put forward by the Government. In practice, the Committee normally weighs and balances between the protection of (the economic value of) existing contracts and other constitutional rights or important social goals pursued by the Bill. Commonly, the argumentation adopted by the Committee may be characterised as laying emphasis on the legitimate expectations of the contracting parties towards the fundaments of their contract (reminiscent as already mentioned above to the German doctrine of Geschäftsgrundlage) disregarding whether these expectations are based on legislation providing the framework for the contract in question or on specific contract clauses. Thus, contractual relations can obtain protection against new statutory law in the courts if the application of statutory law is regarded to manifestly violate these relations. Depending on the circumstances, the level of this constitutional protection can vary from issue to issue, hence, leaving room for judicial interpretation in which constitutional arguments may play a role. For example, in situations where a framework legislation is later amended because of raising environmental concerns the question of constitutional protection becomes an issue: how far should the compensation for private companies relying on the possibility of realize their long-term investment plans reach (what is the appropriate full compensation)? On the one hand, the sovereignty of the Parliament should not be restricted in essential political issues but on the other hand existing arrangements made on a reasonable 
reliance on the continuity and persistence of the policy lines adopted by the government and public authorities should be protected.

From comparative point of view the fact that the Constitutional Committee functions in nonpolitical quasi-judicial manner (e.g. Statements are based on the evidence given by constitutional law experts, Committee follows its own "precedents", there is no political party discipline) is particularly significant. All this results in a unique system of controlling the constitutionality of legislation in which abstract ex ante and concrete case-bound ex post review-mechanism are combined. Importantly, the significance of the "Perustuslakivaliokunta" is reflected to the whole legal system and its Statements hold a special status as a source of law as de facto precedents. ${ }^{21}$ Only with slight exaggeration, one may characterise the weight of these Statements as de facto "constitutional precedents". Concretely this means that if the court later considers the same question of constitutionality as the Constitutional Committee in its statement the court should not, as a rule, see the conflict between the constitution and the legislative provision as manifest.

\subsubsection{Case Law}

As was explained above, the Finnish system of supervision constitutionality is a two-tier system. Constitutional Committee at Parliament makes a priori evaluation of proposed legislation in relation to Constitution and fundamental rights. Courts have a possibility and duty to oversee the possible tension between the application of parliamentary legislation and fundamental rights in concrete cases. Accordingly, it is to be expected that there is a possibility of a tension also between these tiers. These tensions are clearly visible in the Supreme Court case that concerned contract and alleged unconstitutionality. ${ }^{22}$

In this case, a waterpower company had in 1959 proposed for the Ministry a regulation of the flow of water in the river Iijoki. The Government had approved the proposal, and the company had built five plants in the river until the river Iijoki was in 1987 protected by a

\footnotetext{
${ }^{21}$ See Husa (2011) 78-88.

${ }^{22}$ KKO 2006:71. The environmental dimensions of cases like this are dealt with in chapter 4.2.
} 
special legislation. ${ }^{23}$ The company had received compensation provided in 1987 protection legislation for the investments it had made in reliance of the 1959 arrangement. However, that compensation did not contain lost profit. The company sued state of Finland for breach of contract. Crucially, this case is an example of a judgment in which contract law and constitutional law arguments are combined into something we might describe as a genuine constitutional contract law.

The company relied on several grounds, one of which was the unconstitutionality of the 1987 legislation for a violation of the protection of property claiming that the 1987 legislation was unconstitutional. One of the counter argument by the state of Finland was that Parliament is sovereign to make new laws and is not bound by contractual arrangements made on the basis of old laws. Moreover, Constitutional Committee had reviewed the 1987 legislation, and had considered it to be in alignment with fundamental rights. Supreme Court noted the first-tier of a priori supervision of the Parliament itself. Nevertheless, Article 106 of Constitution contains also a duty to give priority to the Constitution if there is an obvious conflict between the application of the parliamentary legislation and Constitution. Even if lost profit is one of the protected rights in the bundle of rights constituting ownership, Supreme Court did not see the discrepancy as obvious (manifest) - with the reference to the opinion of the Constitutional Committee. Simply put, the company lost the case on the basis of constitutional arguments.

In another case Supreme Court had to evaluate the validity of an arbitration clause in a business contract. ${ }^{24}$ One of the parties did not have resources for the arbitration proceedings, and the other party did not offer to pay the whole costs. The arbitrators had according to Finnish law a right to get compensation of their expenses and a fee, and the common practice was that a down payment by the parties was required to cover these before the proceedings would start. ${ }^{25}$ The arbitration clause as such was considered valid in the business contract at hand. However, the outcome would have been unreasonable to the party without any resources. The perspective to evaluate this unreasonability was that of access to justice. Access to justice was specifically mentioned by the Appeal Court in its reasoning.

\footnotetext{
${ }^{23}$ The Act on the Protection of Rapids (35/1987). The main function of the Act is to protect Finland's most precious waterways from construction.

${ }^{24}$ KKO 2003:60.

25 Arbitration Act (967/1992) Section 46 (3) 'The arbitrators have the right to demand an advance on the compensation or a security therefor.'
} 
Constitutional dimension of this case was that the party without resources would have been deprived from the constitutional right to have his case heard by a legally competent court. ${ }^{26}$ Supreme Court concurred with this reasoning with the reference that because of the arbitration clause as such is valid, it would block the possibility of normal proceedings in general courts.

\section{Contract Law's Landscape}

All law is related to the society and culture in question. Finnish contract law is no exception to this. Accordingly, it has several important roots nourishing the more concrete legal outlooks created through legal norms and contract law legislation. These social and cultural background features are the formative context of Finnish contract law. Key expressions of this formative context are the contract law principles - freedom of contract, principle of trust and reliance, and "the third principle" taking various forms as a reaction to adjust contract law norms to changing reality. As a result, we may describe Finland's contract law Nordic as to its nature. ${ }^{27}$

It is of course already a choice to describe any contract law system by reference to its leading principles. The principles-based description leads to an analysis emphasizing the aims and goals of legislation, possible wider systematic impacts of norms the formal application area of which is restricted to only certain specific contracts, the precedents by supreme courts, and most importantly, in relation to Nordic contract law, consequential and practical arguments in concrete cases ('reella överväganden in casu'). ${ }^{28}$

There is one simple reason to justify the choice of this path of principles: Nordic countries, including Finland, have not a comprehensive civil code, not alone a comprehensive code of

\footnotetext{
${ }^{26}$ Constitution Act Section 21 (1) Protection under the law: 'Everyone has the right to have his or her case dealt with appropriately and without undue delay by a legally competent court of law or other authority, as well as to have a decision pertaining to his or her rights or obligations reviewed by a court of law or other independent organ for the administration of justice.'

${ }^{27}$ For a general description, see Ulf Bernitz, 'What is Scandinavian Law', Scandinavian Studies in Law 50 (2007) 14-29 ('flexible, not so doctrinaire approach of Scandinavian law', at 29). See also Husa, 'The Stories We Tell Ourselves (2011).

${ }^{28}$ See, e.g., Johanna Niemi-Kiesiläinen, 'Comparing Finland and Sweden: The Structure of Legal Argument' in Jaakko Husa, Kimmo Nuotio, Heikki Pihlajamäki (eds.) Nordic Law - Between Tradition and Dynamism (Intersentia 2008) 89-108.
} 
contract law. Finnish Contracts Act (FCA, originally 1929) - the most relevant general piece of contract law legislation following in all relevant respects similar Nordic codes in Sweden, Norway, and Denmark (for example in Sweden Avtalslagen) - provides regulation only for contract formation, for invalidity of contracts, and for certain types of authorization, but nothing for example on the interpretation of contracts or consequences of contractual breaches. ${ }^{29}$ Even if the text of that code and its clauses has not been modified (besides one essential amendment on the adjustment of unfair contracts) the application of the clauses has changed, and will change, essentially over its lifespan of 100 years.

The emphasis on aims and goals, and through them towards legal principles of Finnish contract law, does not give a simple right answer to all basic questions of a contract law system. So even if there exists no genuine line of thought privileged by "the Founding Fathers" of modern Nordic contract laws the FCA clearly sets also limits to the possibilities to frame problems as contract law questions. ${ }^{30}$ This is true also when analysing the relations between contract law and constitutional law, as exemplified in the case examples in the previous chapter.

\section{The principle of Freedom of contract}

The FCA does not contain a separate clause providing for the protection of freedom of contract. However, freedom of contract and private autonomy of contracting parties are implied, and strongly supposed, in several clauses in the FCA. For example, the clauses on invalidity of contracts contain direct references to flaws in the formation of the will of the contracting party (physical coercion, mental coercion, mistake in expressing one's will, etc.). ${ }^{31}$ Even on a systematic level, the clauses providing for the formation of contract through offer and acceptance are non-mandatory, i.e. optional, reflecting the starting point that the contracting parties are free to decide over the procedure of contract formation as well as the content of the contract.

\footnotetext{
29 The Contract Act (228/1929). [Contains several later amendments.]

30 There are two recent excellent general presentations of Nordic contract law systems. The book published in 2015 titled The Nordic Contracts Act contains essays in celebration of one hundredth anniversary of those laws. Restatement of Nordic Contract Law from 2016 systematic overview and comments relating to various sections of the laws.

${ }^{31}$ See FCA Chapter 3: Invalidity and Adjustment of Contracts (as amended in 1982).
} 
Finnish contract law discussion on freedom of contract normally brakes this freedom down to its key elements. One of these, the choice to make a contract, or not, is clearly visible in the systematic idea that forcing anyone to make contracts needs specific justification. These exceptions include for example marketing promises individual enough to create legitimate expectations by the other party or the need to protect basic economic means of consumers in a market society like the possibility to open a bank account or to have internet access. The freedom to choose one's contracting party, another of these key elements, has again become limited not only because of mandatory contracting for social reasons (social solidarity) but also for competition law norms (to protect the appropriate functioning of the market mechanism by limiting the effects of dominant market positions). But then again, it is the need for these specific justifications, and specific legislation enabling the restrictions in the basic freedom, that actually justifies the freedom itself as a starting point.

Obviously the most important of these elements is the freedom to choose the terms of the contract, the contractual autonomy sensu stricto. It is compactly visible in the accepted rule of contract interpretation "falsa demonstratio non nocet" meaning that when interpreting the contract the specific meaning meant by the contracting parties should be adopted even if it is contrary to the normal use of the terms. However, from a systematic point of view the most significant feature of Nordic contract law is that it embraces general norm (Generalklausel) enabling the adjustment of contract, that is the content of the contract because of unfairness. This famous Section 36 - a Finnish version of the BGB's famous $\S 242$ - is addressed in a more comprehensive later.

Now, Finnish contract law contains key elements compatible with and supporting freedom of contract principle. More concretely, this freedom is embedded and supposed in the clauses of FCA protecting the significance of the free will of the contracting parties to form contracts. The definition of contract extracted from these norms would be consensus of wills, or meeting of minds. However, it is precisely this definition that is challenged by those who would instead of a straightforward freedom of contract rather see the reliance as the leading principle. Today Finnish contract law contains a possibility besides arguments based on freedom of contract strong lines for arguments relating to reliance and legitimate expectations created by the mutual co-operation under the contract. 
Notably, even though the Constitution Act does not expressly provide the freedom of contract it is deemed to have an undisputed constitutional basis on the praxis of the Constitutional Committee of the Parliament. Crucially, all possible limitations of the freedom of contract must be evaluated according to the established doctrine on restricting constitutional rights with the means of ordinary legislation. ${ }^{32}$

\section{Reliance principle}

Several sections of the FCA contain famous "second subparagraphs". These subparagraphs protect the legitimate expectations of a contracting party in good faith. ${ }^{33}$ More concretely, they are situations where it is obvious that no meeting of minds has taken place but a contract is still seen to be made. The party who made the offer should have realized that the party who received the offer was of the opinion that a meeting of minds had taken place, and the omission to correct this opinion results in a contract with the content of the legitimate expectations by the receiving party.

Moreover, these "second subparagraphs" in the clauses regulating offer and acceptance get systematic support from a key clause of the invalidity of contracts, that of "Treu und Glaube", or good faith and fair dealing in contractual arrangements. ${ }^{34}$ This invalidity is caused by one party behaving contrary to good faith and fair dealing for example by misusing the other party's lack of rational judgment caused by old age or evident misunderstanding of the key characteristics of the situation at hand. Thus, the reliance principle has rather strong institutional support in several clauses in the FCA.

However, it is important to recognize the difference of the tension between freedom and reliance in Finnish contract law in 20th and $21^{\text {st }}$ Centuries, and the German 19th Century quarrels between Will Theory and Reliance Theory, even if that German discussion provided material for the Nordic scholars and legislators for discussion. In the classical German

\footnotetext{
${ }^{32}$ See Husa (2011) 198-199.

${ }^{33}$ Good faith clauses, Section 11(2), Section 19, Section 28(2), Section 32(82), Section 33, Section 34, Section 35, and Section 39. Typical example is Section 39: 'If, according to this Act, the validity of a contract or other transaction depends on the fact that the person to whom the transaction was directed neither knew nor should have known of a circumstance or that he/she otherwise was in good faith, regard shall be had to what he/she knew or should have known when he/she learned of the transaction.'

${ }^{34}$ FCA 36(1): 'If a contract term is unfair or its application would lead to an unfair result, the term may be adjusted or set aside. In determining what is unfair, regard shall be had to the entire contents of the contract, the positions of the parties, the circumstances prevailing at and after the conclusion of the contract, and to other factors.'
} 
debate, it was actually more about the ways to construct the will that was constitutive for the contract. ${ }^{35}$ It was an unanimity about how much this construction should respect only the real state of mind of the party expressing her will, and how much (if at all) the construction could be made on the conception of the expressed will as understood by the receiving party. In the Nordic 20th Century context, the necessity to find a will was substituted by a more radical idea that the concept of contract itself could be directly based on the reliance. In Finnish and Nordic debates, the reliance principle has been linked to the interests of the exchange, that is the market. It would not be efficient to require economic actors to find out the real state of mind of a possible contracting party if the information changed between the contracting parties is matching the normal market behaviour leading to contracts. Keeping this in mind, and the important role given to contextual and consequential arguments, the background of the Nordic scholars supporting the reliance principle should be seen more similar to the German $20^{\text {th }}$ Century "Wertungs- und Interessenjurisprudenz" than to the older classical $19^{\text {th }}$ Century "Vertrauenstheorie". In this century, an even stronger leaning towards normal and typical is evidenced, for example in the case dealing with the parking on private land where pure actions in a social practice (parking a car) were considered enough to constitute a valid contract without any reference to the state of mind of person parking the car. ${ }^{36}$

Supreme Court summarized this Finnish way of understanding the various possibilities of contract formation in a leading precedent in $2010 .{ }^{37}$ There Supreme Court clearly stated that under Finnish law contracts could still be formed and evaluated by an offer-and-acceptance model. However, contracts can and are made by just participating in a social behavioural practice giving rise to rights and duties for the participants. In this latter model, it is not necessary to try to find a separate offer and its final acceptance but the contract is attached to the overall evaluation of the situation. The concrete circumstances in that case were parking a car in a restricted area only marked by specific signs stating, i.e. the monetary payments (fines) if these restrictions were not followed. Supreme Court considered the relations between the person parking the car and the owner of the land to be contractual. This case contains, however, also serious constitutional issues, which we will discuss later in the section 4.3.

\footnotetext{
${ }^{35}$ See Juha Tolonen, NNN, JFT 1973 pp. XXX-YYY.

${ }^{36}$ KKO 2010:23.

${ }^{37}$ KKO 2010:23.
} 


\section{The principle of fairness}

Besides principles finding their justifications in the value of freedom or the aim to enhance functioning markets through reliance principle there is the principle of fairness and its paradigm expression in the general clause enabling adjustment of unfair contracts, Section 36 of the FCA. It states that if a contract or a contractual clause is unfair or if its application would lead to unfairness the clause or the contract can be adjusted. When considering if a contract or a clause of it is unfair the following circumstances must be taken into consideration: the circumstances leading to the contract, the whole content of the contract, the position of the contracting parties, later changes in circumstances, and other relevant matters.

As is obvious from the text of Section 36 there are no general restrictions in the application of this section. Therefore, it applies also to contracts between business parties and not only consumer contracts or contracts between private persons. The court or arbitrator is given full freedom in the adjustment from just declaring the clause null and void to re-writing the clause and/or other parts of the contract to even declaring the whole contract null and void. An adjustment is possible even if the party making a claim for it would have been aware of the unfairness when the contract was made. Consequently, it is generally considered that the possibility to adjust all contracts is part of the "ordre public" of Finnish contract law system.

Section 36 already highlighted its characteristic of "ordre public" nature during the legislative procedure of in the early 1980's. The Constitutional Committee was faced with the problem of retroactivity. ${ }^{38}$ In its short opinion it was bluntly stated that unfair contractual relations do not enjoy the (normal) protection of property. This seems to apply both to contracts, which are overall and totally unfair, but also to those parts of otherwise valid contracts that are (or would lead to) unfair. Section 36 could be given retroactive effects because there was no violation of protection of property in unfair contractual relations.

Principle of fairness finds several normative institutional background and support in the Finnish contract law discussions. ${ }^{39}$ Obviously one way is to connect it directly to Section 36 of FCA, and to the possibility and legal practice of adjustment of contracts. The principle of fairness could be seen to have a role also in other general themes like contractual

\footnotetext{
38 PeVL XX/198Y.

${ }^{39}$ See Juha Pöyhönen (Karhu), Sopimusoikeuden järjestelmä ja sopimusten sovittelu [The System of Contract Law and Contract Arbitration] (Helsinki, Suomalainen Lakimiesyhdistys, 1988).
} 
interpretation (avoiding interpretative outcomes, which would be unfair). Secondly, principle of fairness can be related to norms giving protection to the weaker parties in contractual relations. Contracting parties' resources are sometimes unequally divided giving one of the parties unfair advantage during the bargaining process (inequality of bargaining power). Even if equality before the law normally refers only to the vertical relation between the public authority and the citizen a horizontal dimension of equality can also be detected in the principle of fairness. Principle of fairness could, then, be anchored also in the mandatory legislation protecting weaker parties, for example in the specific norms providing for a kind of "social force majeure" to private persons if their debts are overdue because of unexpected events like sickness, unemployment, divorce or similar events making it too burdensome to fulfil the loan contract as agreed. In situations of "social force majeure", there is often a link to many fundamental rights in the enabling dimension.

Thirdly, principle of fairness can be seen as an elaboration or extension of good faith and fair dealing. Principle of fairness would then have its emphasis not only in the negotiation phase but throughout the whole life span of the contractual relation resembling in this wide scope of application the German civil code's Section 242 on "Treu und Glaube”. Fourthly, as one of the most recent topical discussions in Nordic contract law the principle of fairness can be seen partly overlapping with the principle of loyalty between the contract parties. ${ }^{40}$ Loyalty duties embrace various information obligations and other co-operation measures enabling the smooth execution of the contract. Most significantly, loyalty may require that a contract party must refrain from pushing its own interests to the full if there would be another line of action matching better to the interests of the other party (for example avoiding a significant unilateral loss suffered by the other party).

Besides legal principles, the general part of Finnish contract law contains several parts closely relating to constitutional issues. For example, the rules of invalidity due to lack of genuine consent (because of coercion, duress, and undue influence) can be seen to protect the fundamental right of freedom in conclusion of contracts. Moreover, the requirement of the age of maturity (at the moment 18 years) is related to the right of children to be treated accordingly to their age and maturity that is provided in the constitution. The requirement in

\footnotetext{
${ }^{40}$ See Mats Bryde Andersen and Eric Runesson, 'An Overview of Nordic Contract Law', in Torgny Håstad (ed.) The Nordic Contracts Act (Copenhagen, DJØF, 2015) pp. 15-41.
} 
the specific provisions of FCA that restrictions to professional activities should not be unreasonable is related to the freedom to choose one's profession and earn livelihood on one's own choice. In essence, this right is also directly connected to Constitution Act's right to work and the freedom to engage in commercial activity. ${ }^{41}$

Mandatory contracting is a paradigmatic example of the interest of basic social values breaking classical doctrines of contract law. It is done often to protect and enable access rights. One type of access rights deals with access to basic services like communication in an information society and financial services like bank accounts and basic insurances. Here the service provider has only very limited possibilities to deny the service for private individuals wanting to conclude a contract. Such services are necessarily needed to enjoy many of the fundamental rights, giving the justification to set the business party under an obligation to conclude the contract. A second type of access rights are needed to secure an access to the contract itself. A paradigm example here is the limits of effectivity of an arbitration clause. Firstly, under Finnish law arbitration clauses are not valid in consumers' contracts. ${ }^{42}$ The reason here is to guarantee an easy and affordable possibility to dispute resolution. Secondly, an arbitration clause may not be effective even in a contract between two business parties in special circumstances. As described earlier Supreme Court held that an arbitration clause in a contract over financial services would lead to unfairness and allowed a party to sue in a normal court despite an arbitration clause. ${ }^{43}$

Finally, Corporate Social Responsibility (CSR) is a topical test case. In Finnish contract law debates, the theme has been taken up but not with high enthusiasm. The main counter argument is simply to argue that it is enough for businesses to comply with valid legislation anything more would be unwarranted from a legal point of view even if there could be affordable social or charity reasons to do so. Valid legislation is embedding and giving regard to fundamental and human rights to a sufficient degree. Moreover, from a doctrinal point of view the contract law argumentation to support an idea for the CSR needs to make a reference to horizontal effects of fundamental and human rights. In the preparatory works for

\footnotetext{
${ }^{41}$ Constitution Act Section 18(1): 'Everyone has the right, as provided by an Act, to earn his or her livelihood by the employment, occupation or commercial activity of his or her choice...'.

${ }^{42}$ Consumer Protection Act (38(1978) 12 1d(1) — Handling of disputes (amended in 1997): ‘A term in a contract concluded before a dispute arises, under which a dispute between a business and a consumer shall be settled in arbitration, shall not be binding on the consumer.'

${ }^{43}$ KKO 2003:60
} 
the Finnish Constitution the idea of horizontal effects of fundamental rights was seen possible but not "mainstream". ${ }^{44}$ Moreover, traditionally in Finland the idea was that fundamental rights are "re-written" or transformed in parliamentary legislation, and therefore there is no need, or indeed no possibility, to apply these rights directly. However, with the Constitution Act of 2000, the competence of a retroactive control was given to courts in cases of manifest discrepancy between parliamentary legislation and fundamental rights. The possibilities of an even wider competence to directly apply fundamental rights are related to the doctrine of division of public powers. Tendencies making these issues strongly global set pressures in these respects at least to allow arguments relating to the CSR when deciding over contractual disputes as a kind of global consequential arguments ("globala reella hänsyn").

\section{Illustrations}

This section contains three kinds of illustrations shedding light on the Finnish constitutional contract law. The first one addresses the issue from the point of view of a priori constitutionality control. The second one reopens a Supreme Court case that was already shortly dealt with above. The third issue deals with a situation in which a priori and a posteriori views collide with each other.

\subsection{A priori: Constitutional Law Committee}

Contract law related questions are not the commonplace type of questions that the Constitutional Law Committee works with. However, from time to time there are constitutional issues raising from the Government's legislative bills that also have significant contract law dimensions. A telling example is Government's bill relating to the right-ofoccupancy-dwelling that concerned the constitutional right to property. ${ }^{45}$ Needless to say, constitutional contract law issues are dealt with typically in context of right to property questions. The Constitutional Committee provided its statement on request of the

\footnotetext{
${ }^{44}$ HE 309/1993 vp 29.

${ }^{45}$ HE 100/2002.
} 
Parliament's Environment Committee that typically deals with matters relating to housing, planning, and construction but also to environmental protection and nature conservation. ${ }^{46}$ The interpretation assumed by the Constitutional Law Committee has been later followed in other similar type of issues. ${ }^{47}$

According to the Constitutional Law Committee the constitutional protection of legitimate expectations is connected to contracts in such a manner that the parties to a contract must have a constitutional right to trust to the constancy and stability of relevant parliamentary legislation. Underlying there is a constitutional idea according to which legal certainty has a significant weight in the legal order i.e. the legal system should be predictable and reliable, and thus enabling planning and reasoned decisions as normal course of actions. However, this does not mean that pieces of parliamentary legislation should remain unchangeable, rather, that the will of the legislator cannot be exercised completely freely. Alternatively, in other words, the legislator must take into account the constitutional safeguard for legitimate expectations as a part of broadly understood constitutional protected right to property. In short, the Constitutional Law Committee has interpreted the right to property containing an idea according to which the position of contract parties cannot be unreasonably weakened by means of ordinary parliamentary Acts. Moreover, as underlined by the Constitutional law Committee, when the legitimate expectations are based on legislative Act - as is the case in this example - it is of especial importance that the constitutional protection of legitimate expectations are protected as a part the property rights, and thus reflecting also the "pre1995 " ideas of the protection of normal, usual and reasonable use of property. ${ }^{48}$

\subsection{A posteriori: Courts}

As described above the a priori control of constitutionality, including compliance with fundamental and human rights, is done during the legislation process at the Parliament. When there is a statement by Constitutional Committee on these matters, it is also given a key significance in the a posteriori control by the Courts. A paradigmatic case here is the first case by the Supreme Court where Section 106 was used. The facts of the case have been

\footnotetext{
${ }^{46}$ PeVL 45/2002.

${ }^{47}$ PeVL 4/2008 and PeVL 41/2013.

${ }^{48}$ PeVL 45/2002 p. 4-5.
} 
described already above - it was a question of the compensation for a temporary restriction order during the preliminary assessment of culturally significant environment (old pharmacy). This preliminary assessment did not lead to an actual order of protection. The housing company owning the premises sued Finnish state for the loss of rental income caused by the temporary restriction order. State rejected by claiming that the legislation did not contain such a compensation - actually such a compensation was explicitly denied by the General Assembly of Parliament. However, Constitutional Committee had in its opinion stated that such a possibility should be included in the legislation to avoid a conflict with the fundamental right of protection of property. ${ }^{49}$ Supreme Court used this statement as core argument in its reasoning leading to setting aside the Parliamentary legislation, and enabling the housing company to make a claim for damages.

Another area of examples is also connected to environmental protection. As was explained above, this case - in fact a series of cases of which the most important was highlighted - has to do with the special legislation given to protect the rapids. ${ }^{50}$ The legislation is special because it contains specific reference to the rapids meant to set under protection, not a general norm of protection to be applied by the environmental authorities and courts. Therefore, the constitutionality of such a Parliamentary act has been tried in courts. The cases have been brought up by waterpower companies claiming damages for their long-term investments made on the premise of future building possibilities. In this type of cases the Constitutional Committee had evaluated the specific compensation system established in these special legislations and had considered it to be in line with protection of ownership. ${ }^{51}$ The facts of these cases involved complex circumstances where Finnish state had acted favouring the building plans in other roles than the legislative role.

However, one of the key preliminary questions was could the Parliament legislation be questioned over its constitutionality even when the Constitutional Committee had given its acceptance. The Supreme Court answered this preliminary question affirmative although the outcomes in the cases have been varying. Moreover, courts have emphasized the full-scale use of the possibilities of fundamental rights friendly interpretation as the main method instead of an overruling of the legislation.

\footnotetext{
${ }^{49}$ Report of the Constitutional Committee PeVM 10/1998.

${ }^{50}$ See besides KKO 2006:71, KKO 1991:171, KKO 2000:28 and KKO 2000:97.

${ }^{51}$ KKO 2004:26.
} 


\subsection{Collision of interpretations}

Three auxiliary lines of reasoning legally soften the possibility of the courts to override Parliamentary legislation. Firstly, as just mentioned, courts should primarily exhaust all possibilities of legal interpretation. Secondly, the discrepancy between legislation and fundamental rights must be manifest (obvious). Thirdly, the opinions of the Constitutional Committee should be given a key role in the reasoning, meaning concretely that they should be followed if there are no exceptional circumstances. However, these softening methods are not always enough to block a collision in systematic interpretations. A paradigmatic case here is the Private Parking Supervision situation. It has been dealt with both Constitutional Committee and Supreme Court with strongly clashing outcomes.

The background of the situation is the development of privately managed parking places with outsourced supervision methods. Usually this supervision is executed by private companies specialized in parking services. The core of the legal issue has been the fines included in the supervision in situations where the parking conditions have not been followed (payment, parking time, resident parking permits). These fines were challenged by a private person with a variety of arguments, including a claim that parking fines involve use of public power to an essential extent and could therefore not be executed by private companies. Supreme Court constructed the situation as a contractual one, as described earlier. Yet, even if the basis for the fines were contractual, it was not enough for their validity. Supreme Court had to evaluate whether there really was an essential use of public power. In short, the answer it gave was negative. ${ }^{52}$

During the same period, Constitutional Committee had a similar issue to decide. There was an effort to solve the tense situation of this Private Parking Supervision through legislation, enabling such supervision only under specified conditions. The core question was about these conditions - and actually, whether the supervision powers could include giving fines at all. Despite the name given to the monetary payment for wrongful parking the Constitutional Committee saw it involving the use of public power to an essential extent. ${ }^{53}$ Thus, the

\footnotetext{
${ }^{52}$ KKO 2010:23. The amount of the fine in question was $40 €$ which was the normal level of private fines at that point of time and which was on par with fines ordered by public parking supervision in similar situations.

${ }_{53}^{53}$ Statement 57/2010 of the Constitutional Committee.
} 
Constitution did not allow such power to be transferred to private bodies, and an outcome of requiring the private companies to take the position of municipal parking assistants was created as a solution.

The solution of only allowing municipal parking assistants (and of course in extreme cases police) to give fines for private parking violations did not find accord in Supreme Court's argumentation. It is possible to combine here arguments bound to new forms of contract making to arguments relating to the power of ownership. The parking spaces are part of the land covered by the ownership rules, enabling a wide variety of different uses. It is the variety of these uses that very often make up essential value of the property. To require the service by public authorities in key issues of functionality (as a parking lot) would at the same time mean a restriction in the ownership. This special requirement could be avoided if issuing the fines were not seen containing public power to an essential extent. Supreme Court specifically noted that the private person getting the fine could always invoke normal court procedure to dispute the fine, and thus get legal protection to her interests and rights.

Notwithstanding, this issue is still unsolved and shows how difficult these kinds of collisions are to solve if the Parliament is unable to pass new piece of legislation that would solve the conflict statutorily. ${ }^{54}$

\section{Discussion}

Can we argue that there is a distinct area of law labelled as constitutional contract law in Finland? The answer to this question from a legal systematic point of view is probably a negative one i.e. there is no such distinct area of law. However, as we have shown above these two areas of law have many significant contact points and, what is more, there are many contract law issues that have also a constitutional dimension. Accordingly, we may rather safely argue that these two areas of law are overlapping. In particular, we can see that contract law issues are related to the fundamental rights. Nevertheless, it goes deeper than rights as the case of private parking lots shows; it illustrates that a question may be deemed differently depending on if it is conceived from the point of view of constitutional law or

\footnotetext{
${ }^{54}$ See the Statement of the Constitutional Committee (PeVL 23/2013) which finds a constitutional problem with the Government's bill and, thus, effectively stops the bill on constitutional grounds.
} 
from the point of view of contract law. Albeit, in the future the relations of these two areas of law may become more intertwined than what is the case today. This is because of the constitutionalisation of private law. ${ }^{55}$ This development has to do with a more general trend where we can see a significant rise of the recourse to fundamental rights in debates on various private law issues. Mostly, this has to do with the process of constitutionalisation of private law in general. ${ }^{56}$

Finland, however, is not alone in this. All over Europe, we witness a spectacular rise of the recourse to fundamental rights in debates on civil liability. This is part of a pervasive process of constitutionalisation, of private law in general and tort law in particular.

When considering the constitutionalisation of Finnish contract law three different paths can be detected. Firstly, opening up to arguments relating to constitutions, and especially fundamental and human rights. A good example here is the changing role of norms protecting the weaker parties in contractual relations. Previously the argumentation in the application of these norms focused in the specificity of the norms, creating a kind of closed silos of situations. Now a more general line of thinking is seen when linking this protection to the underlying values protected as fundamental rights (work, housing, health, etc.). From this a more general background where liberty and freedom are supplemented by other social values as the basis of principles but also conceptual structure. Once human and fundamental rights obtain a more prominent and manifest place as the foundation of Finnish legal system their role and significance is reflected throughout the various fields of law, including contract law. There are old and new meeting points between traditional contract law issues and themes and constitutional issues and themes, old points re-interpreted and new points adding to the vocabulary of contract law debates on a case-by-case basis. Essentially, Finnish constitutional contract law is taking shape only gradually, layer by layer.

\footnotetext{
55 According to Jan Smits 'the constitutionalisation of private law can be described as the increasing influence of fundamental rights in relationships between private parties, fundamental rights being those rights that were originally developed to govern the relationships between the State and its citizens', Smits, 'Constitutionalisation of Private Law: a Sceptical View', in Constitutionalisation of Private Law Tom Barkhuysen and Siewert Lindenbergh (eds.) (Martinus Nijhoff, Leiden/Boston, 2006) pp. 9-22.

${ }^{56}$ It should be mentioned, however, that when this topic is discussed in the private law academic literature the mainstream attitude is rather restrictive (see for example Markku Helin, 'Perusoikeuksilla argumentoinnista' [About making arguments on fundamental rights], in: Juhlajulkaisu Jarmo Tuomisto (University of Turku, Turku 2012) pp. 11-30). Even if the possibility of constitutional arguments is allowed, such an argumentation is seen to have only a limited area of relevance. Our prediction is, notwithstanding, that this situation is changing.
} 
Secondly, constitution is receiving a stronger role in the systematic fabric of contract law. It is commonplace that several other fields of law are explicitly linked to constitutional rights. For example, environmental law is fuelled by the fundamental right of environment in setting the responsibility of environment and nature for all actors in its ecological, cultural, and diversity dimensions. Likewise, criminal law gets its starting point in the constitutional provision of legality in nulla poena sine lege provision. Labour law is linked to the special protection of occupations, and competition law to the freedom of trade and profession. Also contract law has its deep level legal background in the provision providing for the protection of property, as described above. Being constitutionally founded does not only mean formal link to the constitution but also a requirement for openness towards the whole system of fundamental rights. Concretely this means that the interaction and overall functioning of fundamental rights make up one element in the framework for an overall legal evaluation of issues at hand. However, unlike some critics have been suggesting ${ }^{57}$, references to fundamental rights is not going to replace more traditional contract law argumentations. In overwhelming number of situations, this perspective will only - but importantly - offer a further point to clarify and modify the arguments used in the contract law reasoning.

Thirdly, as mentioned the catalogue of fundamental rights in the Finnish constitution is quite extensive and comprehensive. Moreover, through memberships of the ECHR and the EU charter of fundamental rights finds also application. The number of fundamental rights relevant in single cases is bound to become numerous, leading to the necessity of weighing and balancing them. Weighing and balancing is not foreign to more traditional private law argumentation but it was seen more as a special case than normal and natural. In more recent legislation in contract law area it is typical that sections of law include provisions requiring an overall evaluation of the situation at hand. Paradigmatic in this respect is Section 36 of FCA. There seems to be room to develop contract law argumentation not only when applying Section 36 but also more generally to learn from the experiences of weighing and balancing of fundamental and human rights. ${ }^{58}$ One concrete topic already taken up the Finnish discussion is the abuse of rights. It has been suggested that like on a general level also contractual rights could be misused, and that this argumentation is exceptionally compelling when there is a link to fundamental rights. Concrete example here is misuse of dominant

\footnotetext{
${ }^{57}$ See Markku Helin, op.cit. pp. 25-27.

58 This seems to be one aspect of an ongoing research for a $\mathrm{PhD}$ thesis by Mr. Joonas Norr from University of Turku where he deals with the additional value of constitutional rights based argumentation in contract law.
} 
market position (through contracts) which are of course null and void also because of competition law rules, but could also be invalidated through contract law arguments. ${ }^{59}$

One final aspect for future on constitutionalisation of contract should not be forgotten. Whatever globalisation means and will mean for law and legal cultures it is clear that we need more dialogue and common grounds for mutual understanding. Because fundamental and human rights, and constitutions also otherwise, invoke by their nature a general challenge for all legal systems they could also - without an idea of a definite and absolute content become interlinks in this kind of discussions. Differences and similarities between various contract law systems could be better understood not so much in formal-technical issues (does already unilateral promises bind or only mutual contracts) than in background value systems (what other values and how are included besides freedom of contract in the system). To conclude, the background issues are the very points where we can expect to see a growing significance and legal relevance of the relationship between constitutional law and contract law.

${ }^{59}$ See Pöyhönen (Karhu) (2003). 